УДК 81-119

https://doi.org/10.31548/philolog2019.03.099

\title{
CONCEPT OF COMMUNICATIVE ROLES IN MODERN LINGUISTICS: CHALLENGES AND RESEARCH PERSPECTIVES
}

\author{
I.P. Ihnatenko, Senior Lecturer at Foreign Languages Department, \\ ORCID ID: 0000-0003-3534-3575 \\ Zh. L. Lemeshko, Senior Lecturer at Foreign Languages Department, \\ National Academy of Fine Art and Architecture \\ E-mail: ignatenkoirina22@gmail.com, zhanna78@bigmir.net \\ http://orcid.org/ 0000-0003-3534-3575, http://orcid.org/ 0000-0002-1913-2674
}

\begin{abstract}
The article addresses the issue of communicative roles from viewpoint of their discursive and cognitive properties. Particular attention has been given to the problem of communicative roles' interrelation with other cognitive-discursive phenomena.

The research aims at identifying the main approaches to the communicative roles in present-day linguistics with a focus on the roles' interplay with related concepts of identity, "face" and subject's positioning.

In handling the research tasks, the paper employs the compound methodology involving the general scientific methods of induction, deduction, introspection and analysis added by the method of generalization of scientific results in different areas of discursive research in order to identify functional properties and cognitive-discursive manifestations of communicative roles.
\end{abstract}

The major findings relate to interdisciplinary significance of the concept of communicative role for such approaches of the modern cognitive-discursive paradigm as critical discourse analysis, conversational analysis, face and politeness theory, positional theory and role identity theory. The paper identifies discourse-forming functions of communicative roles in conversation structuring and development in support of the idea of the role exchange or turn-taking as the basic category of conversational discourse. The cognitive facet of communicative roles relates to their interplay with cognitive-discursive phenomena, including identity, subjective positioning, and personal and social face. The paper focuses on two vectors of interrelations: the discursive facets of identity, subjective position and "face", manifested by communicative roles, and functions of roles in identitybuilding, face-maintaining and subject position forming.

Keywords: communicative role, identity, subject positions, 'face", discursive, cognitive, critical discourse analysis, conversational analysis, face and politeness theory, positional theory, role identity theory.

Introduction. The problem of communicative roles' definition, the means of their actualization and discursive functions remains one of the urgent issues in modern pragmatics and discourse analysis, especially considering the interrelation of this phenomenon with such discursive categories as identity, 'face" and subjective positioning, which may be regarded as a research priority in the present-day interdisciplinary paradigm.

In the framework of the communicative-discursive paradigm, the role is conceptualized as a discourse parameter aimed at the activation of a

(C) I.P.Ihnatenko, Zh. L. Lemeshko

«International journal of philology» | «Міжнародний філологічний часопис» Vol. 10, № 3, 2019 
certain fragment in the linguistic and communicative consciousness of the discourse participants. The role choice is primarily determined by two groups of factors. The static factors involve the type of communicative situation with a fixed set of variables, i.e. social (social status, type of social relations), cultural (traditions), personal (age, gender, psychological type) characteristics of the interactants. The dynamic determinators include the interactant's communicative behavior, i.e. his / her counter roles, as well as changes in the local context and extra-linguistic situation affecting the course of communication (in details - see [1, p.73-74].

Analysis of the latest studies and publications. Communicative roles have been the object of numerous interdisciplinary investigations in sociological, psychological, anthropological and linguistic perspectives. The term "role" was first introduced into science by social psychologist G.H. Mead and anthropologist R. Linton, who understood the role as a dynamic aspect of social status, aimed at fulfilling the rights and obligations assigned to particular status [11, p. 201-215]. In linguistics, and in particular in linguistic pragmatics and discourse analysis, various facets of communicative roles have been studied by such approaches as critical discourse analysis $[1 ; 3 ; 5 ; 6 ; 9 ; 15]$, conversational analysis $[12 ; 13 ; 16]$, positioning theory [8; 17; 18], narrative analysis [3; 4; 17], face and politeness theory $[7 ; 10 ; 14]$, etc.

Despite the interest of the contemporary linguistic schools to the pragmatic and conversational properties of communicative roles, a set of problems associated with the roles' taxonomies, their discursive functions and interrelations with other discursive phenomena remains virtually unexplored. Not less debating is the point of categorical status of the role change / turn-taking among other categories of discourse [2]. One more point that deserves attention is the problem of a cognitive basis of the role-playing. Still open is also an issue of identity-building capacities of communicative roles and their relation to public and personal "faces" of interactants.

The purpose of this paper is to identify the principal approaches to the theory and practical analysis of communicative roles in present-day linguistics with the particular focus on the problem of interrelation between communicative role and the concepts of identity, "face" and subject's positioning.

Data and methods. In handling of our research tasks, we use the complex methodology based on general scientific methods of induction, deduction, introspection and analysis added by definitive method aimed at specifying the communicative role and its related concepts together with the together with the generalization method in order to identify functional properties and cognitive-discursive manifestations of communicative roles.

Presentation of the basic research material. The most important contribution to the study of structural and functional characteristics of communicative roles is made within the conversational-analytical theory.

One of the main focuses of conversion-analytical research is a detailed description of the turn-takingbased interaction regularities, that is how the acceptance and support of the role proposed by the interlocutor or, viceversa, the role rejection determines the course of conversation, structure and content of the whole dialogue $[1$, c. $155-$ $164 ; 12 ; 13]$. With this approach, it is difficult to disagree with the opinion about the role exchange as a basic category of 
conversational discourse that coordinates participants' speech acts on "negotiation" and agreement of counter roles, thus resulting in interaction "shared" meaning [2, c. 6-11].

Some new insights into the problem of communicative roles have been proposed by $\mathrm{H}$. Sacks in his conception of Membership Categorization Analysis [12; 16], introducing (as a part of social categories and their associated activities) the notions of categorical, operational and relational identities, which embody the socially constructed, conventional component of participants' discursive behavior, further adapted to the local discursive context by means of communicative roles.

A critical discourse analysis $[1 ; 3 ; 5$; $6 ; 9 ; 15]$ examines roles as a manifestation of institutional subjectivity with a focus on asymmetric communication rights of agents and clients of institutions, which determines their unequal status-role characteristics. For this sphere of discursive research, it is important to identify ideological implications of role-playing regarding the free or institutionally biased choice of roles by institutional discourse participants. For example, the roles of both agents and "clients" of institutional discourses, as well as their basic concepts, are sufficiently foreseen because of their association with certain narrative-role scenarios (Conservative policy predicts, among others, the scenario of protecting "Western civilization from the threat of modernistic culture and totalitarian governments", with corresponding roles of politicians).

Of particular importance is the concept of role in positioning theory [8; $17 ; 18]$ as one of the influentinal "branches" of narrative analysis $[3 ; 4 ; 16]$. The starting points of positioning theory are as follows: subject positions comprise a set of knowledge / ideas about conventional distribution and exercise of rights and responsibilities in interpersonal relationships; in turn, such conventions are derived from narrative macrocultural, macrosocial scenarios, which are part of the background knowledge of communicators formed by a set of "lived" interactions, internalized texts, as well as dominant discourses.

It follows that any social and communicative actions are "inscribed" in the story lines. During interaction with others, each of the interactants can support more than one storyline, that is, position himself / herself in the framework of several cultural scenarios, which must be mutually consistent to avoid communicative conflict. Coordination of positions and scenarios is ensured by congruent (paired) communicative roles.

The founders of this theory Davies and Harre define positioning as the "discursive process whereby selves are located in conversations as observably and subjectively coherent participants in jointly produced story lines. There can be interactive positioning in which what one person says positions another" [8, p. 48]. Hence it follows that the choice of communicative roles is initially determined by 'subject position' as "a conceptual repertoire and a location for persons within the structure of rights for those that use that repertoire" [8, p. 48]. However, this version of self is undergoing changes since it must be adopted to the requirement of the local interaction. As a result, the communicative role as a consequence of subject positioning begins to affect the cause (that is the subject position) itself. In other words, a certain set of the performed roles forms new positions.

In addition to the subject positions, an equally important aspect of the study of roles is the correlative facet of

(C) I.P.Ihnatenko, Zh. L. Lemeshko

«International journal of philology» | «Міжнародний філологічний часопис» Vol. 10, № 3, 2019 
concepts "role" and "identity" in one-tomany and one-on-one interactions. As N.Kravchenko points out, both the role choice and role construction are based on cultural, social, and personal identity processes [10, p. 145]. The notion of identity is closely related to the concept of face as associated with positively evaluated attributes that the claimant wants others to acknowledge (explicitly or implicitly), and with negatively evaluated attributes that the claimant wants others not to ascribe to him / her. Spencer-Oatey [14, p. 644]. Of particular interest in this vein is identification the face-building capacity of different types of communicative roles. Thus, the social / identity face is manifested by social (institutional, categorical) roles as the role invariants while the quality / personality face relies on individual or operative roles [10].

Conclusion. The major finding of this paper is that the concept of communicative role represents an overlap point of interdisciplinary inquiry of positional theory, critical discourse analysis, conversational analysis, face

\section{Список використаних джерел}

1.Кравченко Н. К. Дискурс и дискурс-анализ: краткая энциклопедия. Киев : «Интерсервис», 2017. 286 с.

2.Кравченко Н. К. Мена коммуникативных ролей как конститутивная категория дискурса. Вісник Харківського національного ун-ту. 2013. № 1052. C. 6-11.

3. Кравченко Н. К. Практическая дискурсология: школы, методы, методики современного дискурс-анализа. Луцьк: Волиньполиграф, 2012. 251 с.

4. Bamberg M. Who am I? Narration and its contribution to self and identity. Theory \& Psychology. 2011. Vol. 21(1). P. 3-24.

5. Bamberg, M., De Fina, A., \& and politeness theory, role identity theory and other influential approaches in the framework of the present-day cognitivediscursive paradigm. The main facets of communicative roles investigation relate to their structural and semantic function in the organization and development of the dialogue, which allows scientists to distinguish the turn taking / role exchange as the basic regularity of conversion and the main category of conversational discourse. In addition to the discursive aspect of the communicative role, the cognitive component of the role is equally important. The latter is primarily studied in terms of the roles' relationship with cognitive-discursive phenomena such as identity, subjective positioning, and personal and social face. It was revealed that the communicative roles are conceptualized, on the one hand, as discursive manifestations of identity, subjective position and "face", and, on the other hand, are viewed in the framework of the roles functions in identity-building, face-maintaining and subject position forming.

Schiffrin, D. Discourse and identity construction / Ed. by K. Luyckx, S. Schwartz \& V. Vignoles, Handbook of identity theory and research, Berlin, Germany: Springer. 2011. P. 177-199.

6. Benwell, B. \& Stokoe, E. Discourse and identity. Edinburgh: Edinburgh University Press. 2005. 314 p.

7. Brown P., Levinson S. Politeness: Some Universals in Language Use. L., N. Y. : CUP, 1987. 345 p.

8. Davies B., Harré R. Positioning: The discursive production of selves. Journal for the theory of social behavior. 1990. Vol. 20 (1). P. 43-63.

9. Fairclough, N. Analysing Discourse: Textual analysis for social research. New York and London.

(C) I.P.Ihnatenko, Zh. L. Lemeshko

«International journal of philology» | «Міжнародний філологічний часопис» Vol. 10, № 3, 2019 
Routledge. 2003. 288 p.

10. Kravchenko N., Pasternak T. Claim for identity or personality face: The Oscar winners' dilemma. Lege artis. Language yesterday, today, tomorrow. The journal of University of SS Cyril and Methodius in Trnava. Warsaw: De Gruyter Open. 2018. Vol. III (1). P. 142178.

11. Mitchell A. "George Herbert Mead and the Unity of the Self." European Journal of Pragmatism and American Philosophy. 2016. Vol 8(1). P. 201-215.

12. Sacks H. Lectures on conversation. Oxford : Wiley-Blackwell. 1992. $1520 \mathrm{p}$.

13. Sidnell J. Conversational Analysis - Comparative Perspectives. University of Toronto : Cambridge University Press. 2009. 460 p.

14. Spencer-Oatey $\mathrm{H}$. Theories of identity and the analysis of face. Journal of pragmatics. 7007. Vol. 39. P. 639-656.

15. Stets J. E., Burke P. J. Identity theory and social identity theory. Social Psychology Quarterly. 2000. Vol. 63. P. 224-237.

16. Stokoe E. Moving forward with membership categorization analysis: Methods for systematic analysis. Discourse Studies. 2012. Vol.14(3). P. 277-303.

17. Swan D. Positioning as a means of understanding the narrative construction of self: A story of lesbian escorting. Narrative Inquiry. 2001. Vol. 10 (2). P. 403-427.

18. Wetherell M. Positioning and interpretative repertoires: Conversation analysis and poststructuralism in dialogue. Discourse and Society. 1998. Vol. 9. P. 387-412.

\section{References}

1. Bamberg, M. (2011). Who am I? Narration and its contribution to self and identity. Theory \& Psychology, 21(1), 324.

2. Bamberg, M., De Fina, A., \& Schiffrin, D. (2011). Discourse and identity construction / Ed. by K. Luyckx, S. Schwartz \& V. Vignoles, Handbook of identity theory and research, Berlin, Germany: Springer, 177-199.

3. Benwell, B. \& Stokoe, E. (2005). Discourse and identity. Edinburgh : Edinburgh University Press.

4. Brown, P., Levinson, S. (1987). Politeness: Some Universals in Language Use. L., N. Y. : CUP.

5. Davies, B., Harré R. (1990). Positioning: The discursive production of selves. Journal for the theory of social behavior, 20 (1), 43-63.

6. Fairclough, N. (2003). Analysing Discourse: Textual analysis for social research. New York and London. Routledge.

7. Kravchenko, N., Pasternak, T. (2018). Claim for identity or personality face: The Oscar winners' dilemma. Lege artis. Language yesterday, today, tomorrow. The journal of University of SS Cyril and Methodius in Trnava. Warsaw: De Gruyter Open, III (1), 142-178.

8. Kravchenko, N. (2017). Diskurs i discurs-analiz: kratkaia entsyklopediya. Kiev: Interservis.

9. Kravchenko, N. (2013). Mena komunikativnyh roley kak konstitutivnaya kategoriya diskursa. Visnyk Kharkivskoho natsionalnihi un-tu, 1052, 6-11.

10. Kravchenko, N. (2012). Prakticheskaya diskursologiya: shkoly, metody i metodiki sovremennogo diskursanaliza. Lutsk : Volynpoligraf.

11. Mitchell, A. (2016) "George Herbert Mead and the Unity of the Self," European Journal of Pragmatism and American Philosophy, 8(1), 201-215.

12. Sacks, H. (1992). Lectures on conversation. Oxford: Wiley-Blackwell.

13. Sidnell, J. Conversational

(C) I.P.Ihnatenko, Zh. L. Lemeshko

«International journal of philology» | «Міжнародний філологічний часопис» Vol. 10, № 3, 2019 
Analysis - Comparative Perspectives. University of Toronto: Cambridge University Press.

14. Spencer-Oatey, H. (2007). Theories of identity and the analysis of face. Journal of pragmatics, 39, 639-656.

15. Stets, J. E., \& Burke, P. J. (2000). Identity theory and social identity theory. Social Psychology Quarterly, 63, 224-237.

16. Stokoe, E. (2012). Moving forward with membership categorization analysis: Methods for systematic analysis. Discourse Studies, 14(3), 277303

17. Swan, D. (2001). Positioning as a means of understanding the narrative construction of self: A story of lesbian escorting. Narrative Inquiry, 10 (2), 403427

18. Wetherell, M. (1998). Positioning and interpretative repertoires: Conversation analysis and poststructuralism in dialogue. Discourse and Society, 9, 387-412.

\section{КАТЕГОРІЯ КОМУНІКАТИВНИХ РОЛЕЙ В СУЧАСНІЙ ЛІНГВІСТИЦІ: ПРОБЛЕМИ І ПЕРСПЕКТИВИ ДОСЛІДЖЕННЯ}

\section{І. П. Ігнатенко, Ж. Л. Лемешко}

Анотація. Стаття присвячена проблемі комунікативних ролей в аспекті їхніх дискурсивних та когнітивних характеристик. Особлива увага приділяється питанню взаємозв'язку комунікативних ролей з іншими когнітивно-дискурсивними параметрами. Метою дослідження є визначення основних підходів до усвідомлення комунікативних ролей у сучасній лінгвістиці з огляду на особливості взаємодії ролей із суміжними феноменами ідентичності, “обличчя” та суб'єктного позиціювання.

Для вирішення завдань дослідження в роботі використовується комплексна методика, що включає загальнонаукові методи індукції, дедукції, інтроспекції $і$ аналізу, у поєднанні з дефінітивним методом і методом узагальнення наукових результатів в різних сферах дискурсивних досліджень з метою виявлення фуннкціональних властивостей та та когнітивно-дискурсивних маніфрестацій комунікативних ролей.

Основні висновки дослідження стосуються міждисциплінарної значущості поняття комунікативної ролі для таких напрямів сучасної когнітивно-дискурсивної парадигми, як критичний дискурс-аналіз, конверсаційний аналіз, теорія обличчя та ввічливості, теорія суб'єктного позиціювання та теорія рольової ідентичності. У статті визначено дискурсотвірні фрункції комунікативної ролі в структуруванні та розвитку діалогічної інтеракції, що свідчить на підтримку ідеї про те, що зміна комунікативних ролей є основною категорією розмовного дискурсу. Когнітивний аспект комунікативної ролі пов'язаний із взаємодією цього френомену з такими когнітивно-дискурсивними явищами, як ідентичність, суб'єктне позиціювання та індивідуальне i соціальне обличчя. У статті висвітлюються два вектори взаємозв'язків: дискурсивні вияви ідентичності, суб'єктного позиціювання та

(C) I.P.Ihnatenko, Zh. L. Lemeshko

«International journal of philology» | «Міжнародний філологічний часопис» Vol. 10, № 3, 2019 
«обличчя», маніфестовані комунікативними ролями, та фрункиії ролей у формуванні зазначених категорій.

Ключові слова: комунікативна роль, ідентичність, суб'єктні позиції, «обличчя», дискурсивний, когнітивний, критичний дискурс-аналіз, конверсаційний аналіз, теорія обличчя та ввічливості, теорія позиціювання, теорія рольової ідентичності. 